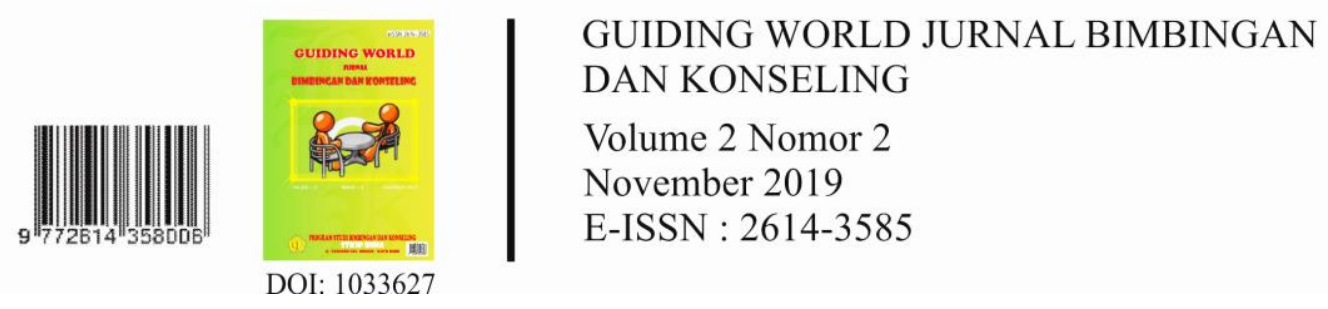

\title{
Analisis Nggahi Ncemba dalam Masyarakat Bima di Kecamatan Sape Kabupaten Bima
}

\author{
Irham \\ STKIP Bima \\ E-mail: irham.husain68@gmail.com
}

\section{Abstrak}

Nggahi Ncemba merupakan salah satu jenis sastra lisan (folklor) yang tumbuh dan berkembang pada masyarakat Bima di Kecamatan Sape Kabupaten Bima. Sebagai bagian dari tradisi, Nggahi Ncemba kiranya perlu mendapatkan perhatian dari masyarakat penggunanya, maupun pemerintah. Yaitu, dengan cara meningkatkan apresiasi terhadap tradisi tersebut, seperti melakukan inventarisasi dan menganalisisnya. Hal ini dilakukan sebagai upaya pelestarian terhadap budaya lokal yang merupakan bagian dari kekayaan budaya nasional, sehingga generasi yang akan datang dapat mengenalnya. Selain itu, upaya seperti ini dilakukan untuk membentengi terjadinya akulturasi budaya tradisional. Maka penelitian yang dilakukan ini adalah bagian dari bentuk apresiasi penulis terhadap budaya tradisional dalam rangka inventarisasi, melestarikan, dan untuk menganalisis bentuk, fungsi dan nilai/makna yang terkandung dalam Nggahi Ncemba tersebut pada masyarakat penggunanya, yaitu masyarakat Bima di Kecamatan Sape Kabupaten Bima.

Penelitian ini dilakukan dengan menggunakan metode deskriptif kualitatif. Metode deskriptif kualitatif adalah metode yang menggambarkan suatu masalah dengan uraian kata-kata serta dipisahkan menurut kategori untuk memperoleh kesimpulan. Sumber data dalam penelitian ini adalah masyarakat Bima yang tinggal di Kecamatan Sape Kabupaten Bima. Sedangkan sampel dalam penelitian ini adalah perwakilan masyarakat Kecamatan Sape yang diambil secara acak dari tiap-tiap desa yang berjumlah 17 desa (masing-masing dua orang tiap desa). Cara menentukannya adalah dengan menggunakan teknik acak atau random sampling, sehingga jumlah responden/informan yang dikenai sampel sebanyak 34 orang. Objek Penelitiannya adalah bentuk, fungsi dan nilai yang terkandung dalam Nggahi Ncemba. Data dalam penelitian ini adalah bentuk, fungsi dan nilai yang terkandung dalam Nggahi Ncemba. Metode pengumpulan data, yaitu metode observasi, wawancara, rekaman, transkripsi/terjemahan, dan dokumenter. Sedangkan metode analisis data adalah identifikasi, klasifikasi dan interpretasi.

Berdasarkan metode yang digunakan, maka dalam pembahasan penelitian ini penulis menguraikan data yang diperoleh di lapangan dengan mengklasifikasikan, menginterpretasikan dan menganalisisnya. Data yang diperoleh sebanyak 50 Nggahi Ncemba yang diklasifikasikan ke dalam empat bentuk, yaitu pepatah, perumpamaan, pemeo atau pribahasa. Sedangkan fungsi dan nilai yang terkandung dalam Nggahi Ncemba, yaitu religi, pendidikan, moral, sosial, dan ekonomi.

Kata kunci : Analisis, Nggahi Ncemba, Masyarakat Bima di Kecamatan Sape 


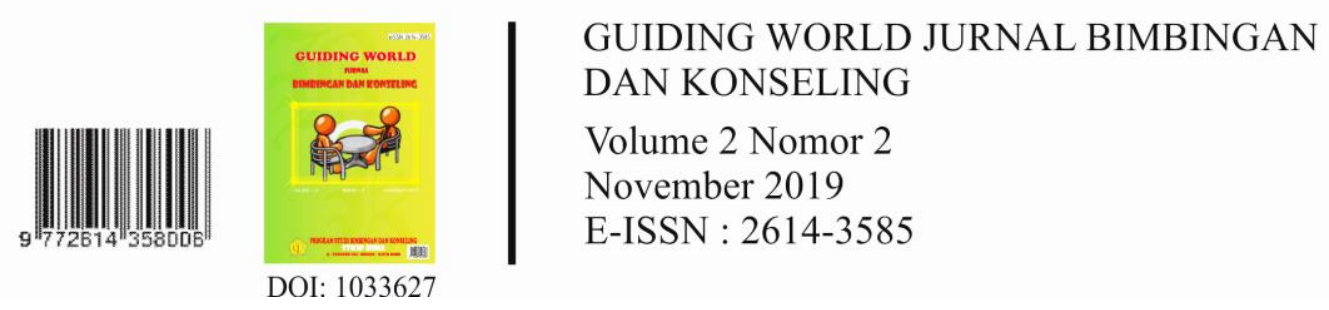

\section{PENDAHULUAN}

\section{Latar Belakang}

Jika kita melihat kehidupan sosial budaya masyarakat Nusa Tenggara Barat (NTB), maka akan tampak masyarakat yang heterogen. Aneka ragam kelompok sosial dan kelompok etnis yang menghuni daerah Nusa Tenggara Barat (NTB) memperlihatkan adat kebiasaan, tingkat pendidikan dan corak kehidupan beragama yang berbeda-beda.

Kelompok masyarakat yang berasal dari berbagai daerah di Indonesia maupun warga asing mengalir terus ke NTB. Dalam keadaan seperti ini tidak dapat kita mengelak terjadinya proses akulturasi di antara kelompok yang bersangkutan untuk saling menyesuaikan diri. Pergaulan sosial budaya antarkelompok itu tentunya mengakibatkan terjadinya pertukaran budaya atau bahkan proses perkembangan budaya. Unsur-unsur kebudayaan yang sudah menjadi ciri khas kini dianggap tidak sesuai lagi dengan keadaan dan perkembangan zaman, lalu segera dilupakan dan mengalami kepunahan. Sebaliknya, akan tumbuh unsur-unsur kebudayaan baru sebagai pengganti kebudayaan lama yang dianggap tidak lagi sesuai dengan zamannya.

Kehilangan dan kepunahan itu mungkin tampaknya tidak penting, tetapi akibatnya akan terasa pada pembinaan nilai-nilai baru kebudayaan asing yang menjadi kebudayaan nasional. Menyelamatkan kebudayaan itu penting karena punahnya suatu kebudayaan, maka hilang pula nilai-nilai yang terkandung di dalamnya.

Demikian pula halnya dengan kebudayaan masyarakat (folklore) di daerah Nusa Tenggara Barat, lebih khusus yang dibahas dalam penelitian ini adalah kebudayaan masyarakat (folklore) Bima di Kecamatan Sape, yang kini mengalami akulturasi dengan kebudayaan yang dibawa oleh para pendatang. Derasnya arus pendatang beserta unsur-unsur pendatang baru itu, baik yang datang dari berbagai daerah di Nusantara, maupun yang datang dari negeri lain, memaksa masyarakat Kecamatan Sape untuk menyesuaikan diri dengan keadaan dan perkembangan baru.

Walaupun percampuran antarkebudayaan itu ditinjau dari kepentingan nasaional dapat menguntungkan perkembangan kebudayaan Indonesia, sebaliknya bisa menimbulkan berbagai akibat bagi kebudayaan daerah. Antara lain, musnahnya budaya anggudu sebagai ciri khas kelompok masyarakat setempat karena tertelan oleh perkembangan masyarakat itu sendiri.

Setiap kebudayaan selalu mengalami perubahan serta perkembangan secara dinamis sesuai dengan perkembangan masyarakat pendukungnya. Walaupun demikian, jika pembaruan yang terjadi tidak sesuai dengan masyarakat pendukungnya untuk menyerap unsur-unsur kebudayaan baru, cepat atau lambat hal itu akan menimbulkan keresahan sosial. Apabila satu generasi belum sempat menikmati dan menghayati kebudayaan yang membinanya kemudian dihadapkan pada kebudayaan yang masih asing, maka besar kemungkinan akan terjadi kesulitan yang dialami dalam usaha penyesuain dirinya dengan kebudayaan yang asing tadi. 


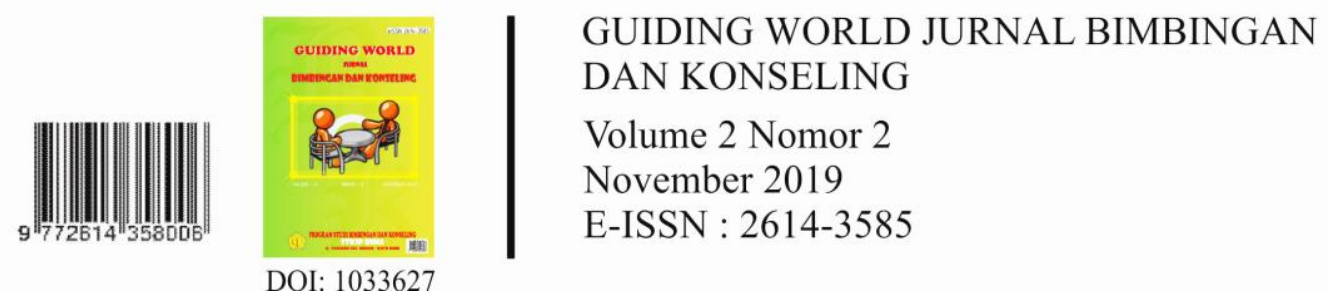

Keresahan-keresahan sosial yang timbul di masyarakat dewasa ini menunjukkan betapa tidak seimbangnya perkembangan unsur-unsur kebudayaan. Untuk mengatasi perkembangan yang pincang itu tidak mudah, apalagi dalam masyarakat yang sedang membangun di segala bidang. Jadi apa yang mungkin dikerjakan untuk memperkecil ketegangan sosial dan keresahan masyarakat? Untuk mengusahakan perkembangan yang harmonis itu diperlukan pengetahuan tentang unsur-unsur kebudayaan lama dan unsur-unsur kebudayaan baru yang saling berpadu dan menimbulkan proses akulturasi itu.

Kebudayaan masyarakat Sape sekarang ini pun dapat dianggap sedang mengalami proses akulturasi dengan segala akses-aksesnya yang berupa keresahan sosial dan kepincangan ataupun ketidakserasian dalam proses perkembangannya. Adapun usaha yang perlu dilakukan adalah mengidentifikasi unsur-unsur kebudayaan masyarakat Bima di Kecamatan Sape yang lama serta mendokumentasikan segala data yang dapat dikumpulkan. Di samping itu, perlu juga diadakan identifikasi unsur-unsur kebudayaan baru yang melanda kehidupan sosial budaya masyarakat Sape.

Secara historis, orang Bima atau Dou Mbojo dibagi atas dua kelompok yakni kelompok penduduk asli dan kelompok penduduk pendatang. Kelompok penduduk asli disebut dou Donggo yang menghuni kawasan bagian barat teluk, yang tersebar di gunung dan lembah. Mereka mengasingkan diri dengan penduduk pendatang. Antara dua kelompok belum terjadi pembauran (dalam Tajib, 1995: 32).

Dari hasil penelitian Zollinger (1842), ia berpendapat Orang Donggo maupun penduduk Bima di sebelah timur laut teluk (Donggo Ele). Menunjukkan karakteristik yang jelas sebagai ras bangsa yang lebih rendah, kecuali beberapa corak yang menunjukkan seperti orang-orang Bima yang bermukim di sebelah timur teluk. Sedangkan Elbert Johannes berkesimpulan bahwa pada dasarnya orang yang tinggal di sekitar ibukota adalah ras bangsa yang lebih tinggi, hidup pula ras bangsa campuran yang bertalian dengan orang Bugis dan Makasar yakni ras bangsa Melayu muda. (dalam Tajib, 1995: 33). Selaras dengan pendapat tersebut, maka dapat disimpulkan bahwa masyarakat Bima yang berada di Kecamatan Sape yang kini bermukim pula di sebelah timur teluk Bima.

Terkait dengan bahasa yang digunakan oleh masyarakat Bima (Mbojo) sebagai alat komunikasi keseharian, maka hal ini dapat diketahui dengan membandingkan kebudayaan dan bahasa di sekitarnya, yang dibandingkan terutama kata benda seperti padi, tebu, kelapa, besi. Kata-kata tersebut tersebar di kawasan Lautan Teduh dan Lautan Hindia dari Madagaskar sampai ke Pulau Pas, dari Pulau Formosa sampai ke Pulau Jawa dan Hindia Belakang. Bahasa yang digunakan di kawasan tersebut termasuk dalam kelompok bahasa Austronesia (dalam Tajib, 1995: 34).

Menilik ke dalam bahasa Bima, kata-kata dan nama benda banyak terdapat kata-kata benda dalam bahasa Bima yang sama dengan kata-kata dalam bahasa Jawa Kuno, utamanya yang masih dipergunakan oleh sisa penduduk asli yang tersimpan dalam bahasa Donggo, bahasa Tarlawi dan bahasa Kolo. Hanya kadang-kadang pengucapanya sudah berubah atau pengucapannya tetap, artinya 


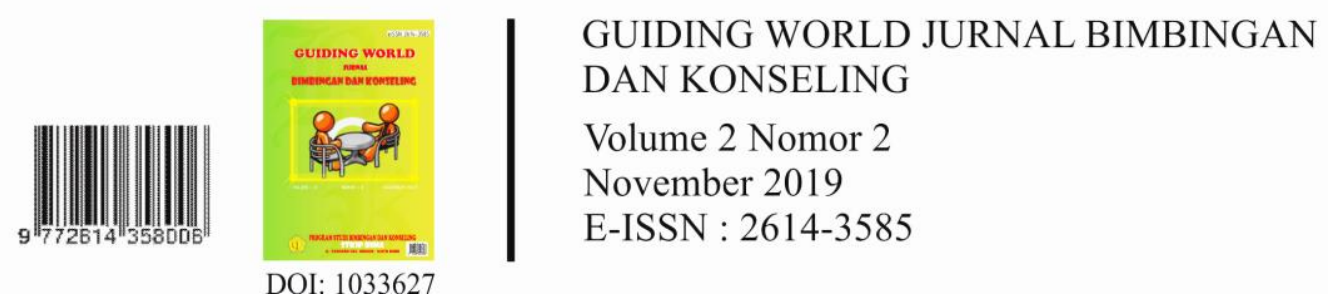

berubah. Perubahan tersebut terjadi karena hubungan yang terputus, sehingga komunikasi antara penduduk induk sumber bahasa terputus pula. Akibatnya, hidup menyendiri dalam jangka waktu yang cukup lama yang membuat pengucapan atau arti bahasa asli itu berkembang dalam corak yang berbeda antara satu dengan lainnya.

Melalui perbandingan bahasa, maka akan mengukuhkan pendapat bahwa orang Bima bagian dari kelompok induk ras bangsa Mongoloid yang datang dari Hindia belakang, dan bukan dari ras bangsa Arafura. Sehingga jelaslah bahwa Bima atau Dana Mbojo menempatkan dirinya sebagai garis pemisah batas tertimur induk ras bangsa Melayu dan pengaruh kebudayaan Hindu/kebudayaan Jawa (Tajib, 1995: 34).

Sebagai pembuktian, maka kita bisa melihat beberapa kata dalam bahasa Bima yang sama dengan bahasa Jawa Kuno. Contoh persamaan antara bahasa Bima dan bahasa Jawa Kuno antara lain : B: ama, JK: ama 'ayah' B: ina, JK: ina 'ibu' B: imba, JK: imba 'meniru' B: uma, JK: umah 'rumah' B: kica, JK: kica 'kera' B: kuta, JK: kuta 'pagar' B: ringa, JK: rengo 'dengar' $\mathrm{B}$ : do'o, JK: dooh ‘jauh', dan seterusnya.

Kebudayaan masyarakat Bima di Kecamatan Sape yang hidup dan berkembang sejak masa lalu hingga sekarang berkembang dengan menggunakan bahasa Bima asli. Sape sebagai daerah dataran tinggi bagian Timur Bima, kini masih kental dengan watak dan karakter kesukuannya. Kebudayaan-kebudayaan yang dianut oleh para nenek moyangnya kini masih dianut oleh masyarakat setempat secara turun-temurun. Tradisi kebudayaan (folklore) yang dimaksud di antaranya adalah tradisi tenun tembe nggoli (sarung tenun), cerita rakyat, mpama (dongeng), rawa Mbojo (nyanyian rakyat Bima), patu (puisi rakyat), mpama pehe (teka-teki tradisional), nggahi ncemba (ungkapan) dan masih banyak tradisi kebudayaan (folklore) lain yang belum diketahui oleh peneliti. Hal ini menunjukkan masyarakat Donggo sebagai bagian dari masyarakat asli Bima, kini kaya akan budaya (folklore). Namun sesuai dengan perkembangan zaman, tidak semua tradisi kebudayaan (folklore) itu masih dianut oleh masyarakat setempat.

Mengingat ruang lingkup kehidupan kebudayaan masyarakat Sape sangat luas, maka yang diutamakan dalam pengumpulan data dibatasi pada folklor bentuk lisan saja, yaitu Analisis nggahi ncemba dalam masyarakat Bima di Kecamatan Sape.

Upaya identifikasi folklore bentuk lisan ini adalah bentuk usaha untuk menyelamatkan aset budaya sebagai kekayaan lokal masyarakat setempat sekaligus sebagai bagian dari kekayaan bangsa Indonesia. Untuk mengetahui secara langsung keberadaan folklore dalam bentuk lisan yang hidup dan berkembang dalam masyarakat Bima di Kecamatan Sape, maka penulis mengambil judul penelitian: "Analisis nggahi ncemba dalam masyarakat Bima di Kecamatan Sape Kabupaten Bima".

\section{Rumusan Masalah}

Berdasarkan latar belakang di atas, maka permasalahan penelitian ini dapat dirumuskan, yaitu bagaimanakah bentuk, fungsi, dan nilai yang terkandung dalam Nggahi Ncemba bagi masyarakat Bima di Kecamatan Sape Kabupaten Bima? 


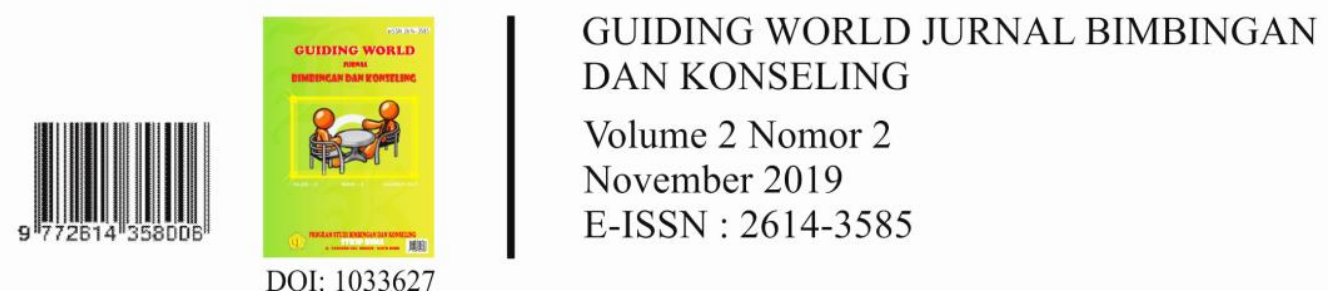

\section{Tujuan Penelitian}

Tujuan penelitian ini adalah ingin mengetahui dan mendeskripsikan bentuk, fungsi, dan nilai yang terkandung dalam Nggahi Ncemba bagi masyarakat Bima di Kecamatan Sape Kabupaten Bima.

\section{Landasan Teori}

Adapun istilah-istilah yang berkaitan dengan teori dalam penelitian ini sebagai berikut.

\section{a. Folklore}

Pengertian yang terkandung dalam folklore kiranya diperlukan suatu uraian. Kata folklore berasal dari dua kata Bahasa Inggris: folk dan lore. Menurut Alan Dundes, seorang ahli folklore Amerika istilah folk berarti kelompok orang yang memiliki ciri-ciri pengenal kebudayaan yang membedakanya dari kelompok lain. Ciri-ciri kelompok tersebut dapat berupa mata pencaharian hidup yang sama, bahasa yang sama, agama yang sama, tingkat pendidikan yang sama dan lain-lain, tetapi yang terpenting dalam hal ini adalah mereka telah mempunyai suatu tradisi, yaitu kebudayaan yang telah diwarisi secara turun-temurun yang dapat mereka akui sebagai milik kelompok mereka sendiri. Di samping itu, yang penting juga ialah mereka sadar akan identitas kelompok mereka sendiri. Adapun yang dimaksud dengan lore adalah tradisi folk yang diwariskan secara lisan atau tutur kata, atau melalu contoh yang disertai dengan perbuatan.

Jika uraian di atas kita rangkum, definisi folklore dapatlah dirumuskan sebagai "sebagian dari kebudayaan yang tersebar dan diwariskan secara turun-temurun serta bersifat tradisional di antara anggota-anggota kelompok apa saja, dalam versi yang berbeda-beda, baik dalam bentuk lisan maupun contoh yang disertai dengan perbuatan" (Hutomo, 2003: 5).

\section{b. Analisis}

Analisis adalah penjabaran sesudah dikaji sebaik-baiknya atau proses pemecahan persoalan yang dimulai dengan dugaan akan kebenarannya (KBBI, 1991: 37).

\section{c. Ungkapan}

Ungkapan adalah kelompok kata atau gabungan kata yang menyatakan makna khusus "makna unsur-unsurnya sering kali menjadi kabur" (KBBI, 1991: 1105).

Pengertian di atas sejalan dengan pendapat Poerwadarminta (1986: 129) yang mengatakan ungkapan adalah perkataan atau kelompok kata yang khusus untuk menyatakan suatu maksud dengan arti kiasan (seperi 'melihat bulan' yang berarti haid, 'celaka tiga belas' yang berarti celaka sekali).

\section{d. Nggahi Ncemba}

Istilah Nggahi Ncemba berasal dari dua kata, yaitu nggahi (ungkapan atau perkataan), dan ncemba (sindiran). Nggahi Ncemba adalah kelompok kata-kata yang diungkapkan secara lisan yang bermakna sindiran (memiliki makna khusus/makna tersirat). 


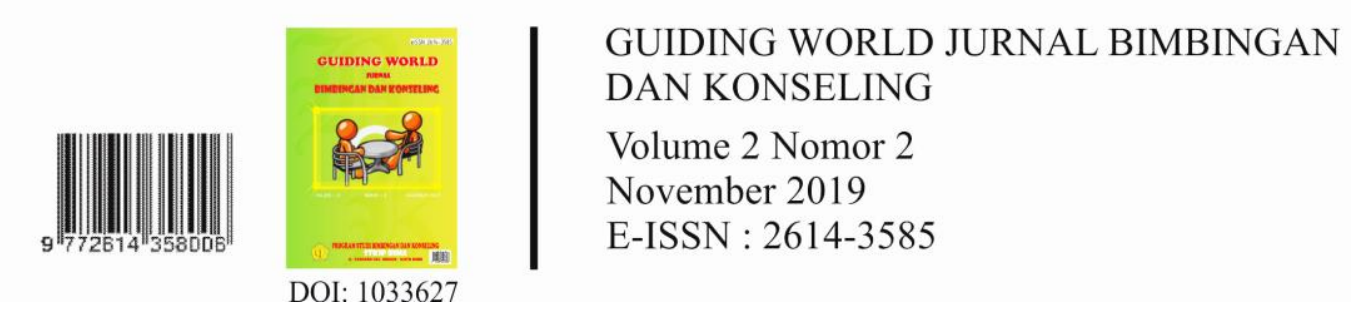

\section{Bentuk Ungkapan}

Bentuk adalah wujud yang ditampilkan "yang tampak" (KBBI, 1991: 119). Menurut Jainuddin (1995:1), bahwa ada tiga bentuk ungkapan, yaitu sebagai berikut.

a. Pepatah

Bentuk ungkapan ini, yaitu sejenis peribahasa yang berisi nasehat atau petuah/ ajaran orang tua-tua.

Contoh: $\quad$ Tena nalari tamparanga

Terjemahannya: Laut tidak akan lari

Maksudnya: Di dalam mengerjakan sesuatu tidak perlu tergesa-gesa, harus tenang tetapi mantap.

\section{b. Perumpamaan}

Bentuk ungkapan ini, yaitu sejenis peribahasa yang mengandung perbandingan yang biasanya menggunakan kata-kata seperti kamma, sangkamma, sangkontu, saurapang yang bermakna "seperti, sebagai, bagaikan, dan laksana" serta ebarak yang berarti 'ibarat'.

Contoh: $\quad$ Kamma jeknek ri lekok paecok

Terjemahan: Bagaikan air di daun talas.

Maksudnya: Kedudukannya goyah.

\section{c. Pemeo}

Bentuk ungkapan ini, yaitu sejenis pribahasa yang dijadikan semboyan.

Contoh: Kualleangitallanga na toalia.

Terjemahnnya: Lebih baik tenggelam daripada surut kembali.

Maksudnya: Pantang mundur dari perjuangan sebelum tercapai citacita.

\section{d. Pribahasa}

Pribahasa adalah kelompok kata atau kalimat yang biasanya berisi maksud tertentu, kadang-kadang berisi nasehat, prinsip hidup, atau aturan tingkah laku.

Contoh: $\quad$ Nggahi rawi pahu

Terjemahnnya: Berkata hendaknya dibuktikan dengan hasil karya yang nyata

Maksudnya: Apa yang dikatakan harus dibuktikan.

\section{Fungsi Ungkapan}

Menurut William R. Baskom, seorang guru besar ilmu folklor di Universitas Berkelei Kalifornia Amerika Serikat, bahwa ada empat fungsi folklor (ungkapan), yaitu:

a. sebagai sistem proyeksi (projective system), yakni sebagai alat pencermin angan-angan suatu kolektif;

b. sebagai alat pengesahan paranata-pranata dan lembaga-lembaga kebudayaan;

61 


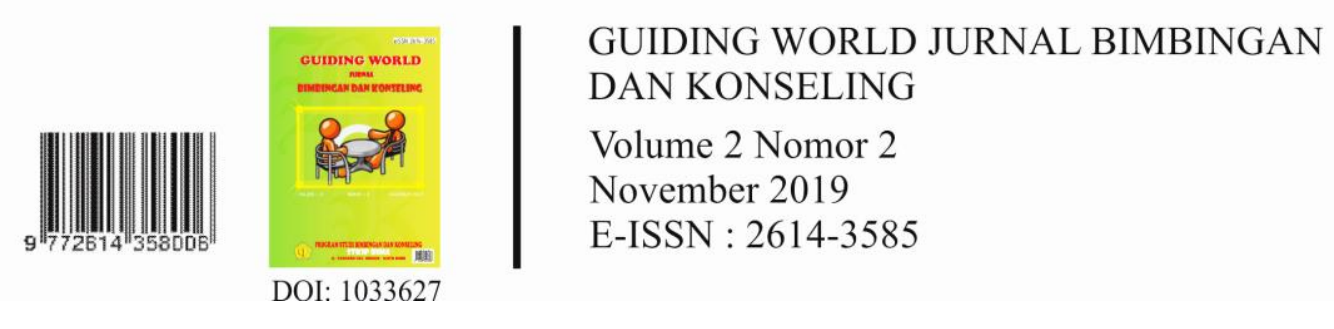

c. sebagai alat pendidik anak (pedagogical device);

d. sebagai alat pemaksa dan pengawas, agar norma-norma masyarakat akan selalu dipatuhi anggota kolektifnya (dalam Danandjaja, 1984:19).

\section{Nilai/Makna Ungkapan}

Nilai adalah hal-hal (sifat) yang penting atau berguna bagi kemanusian (KBBI, 1991:690). Secara objektif kebudayaan berisi aspekaspek kehidupan, baik dalam konteks individu maupun sosial, menyangkut jasmaniah atau rohaniah dan intelektual (Bakker, 1984:38).

Menurut Alimuddin (2004:36), bahwa ada tujuh jenis nilai dalam ungkapan tradisional, yaitu sebagai berikut.

\section{a. Nilai Moral}

Nilai moral atau sering pula disebut akhlak dalam karya sastra tentunya dapat mengajak dan mendidik pembaca untuk menjadi manusia yang berbudi luhur dan bermoral tinggi, sehingga dapat hidup di tengah masyarakat dan dunia pada umumnya, seperti mengajak kerabat untuk menghormati yang lebih tua, tidak suka mengambil milik orang lain dan lain-lain.

\section{b. Nilai Sosial}

Nilai sosial adalah hal-hal yang penting atau berguna bagi kemanusiaan dalam hubungan kemasyarakatan, terutama dalam hubungannya dengan tolong menolong, dan hidup berdampingan dengan penuh asah, asih, dan asuh, seperti membantu tetangga yang susah, mengasuh anak yatim, ikut serta dalam kegiatan gotongroyong dan lain-lain.

\section{c. Nilai Religi/Agama}

Nilai religi adalah nilai-nilai yang berhubungan antara manusia dan tuhannya sehingga karya sastra dapat memberikan suri tauladan bagi kehidupan manusia untuk selalu menahan diri dari perbuatan-perbuatan tercela dan dapat melaksanakan kewajibannya sebagai makhluk yang beragama, misalnya mengajak kerabat untuk beribadah, mengingatkan kerabat agar tidak berbuat sesuatu yang dilarang agama.

\section{d. Nilai Budaya}

Nilai budaya adalah hal-hal yang berkaitan dengan kebiasaan hidup dan tradisi masyarakat dalam upaya pelestarian budaya lokal, yaitu upaya agar generasi-generasi berikutnya tidak larut pada budaya-budaya lain (budaya Barat), misalnya mengajak kita agar tidak melupakan kebiasaan yang baik, terus diwariskan secara turun temurun, agar tidak hilang dan lan-lain.

\section{e. Nilai Ekonomi}

Nilai ekonomi adalah hal-hal yang menjadi taradisi masyarakat sebagai mata pencaharian atau penghasilan tambahan untuk memenuhi kebutuhan sehari-hari dengan jalan yang baik, misalnya mengajak kita agar tekun bekerja untuk memperoleh hasil yang lebih baik, mengingatkan kita agar pengeluarannya diimbangi dengan penghasilan dan lain-lain.

\section{f. Nilai Estetika}




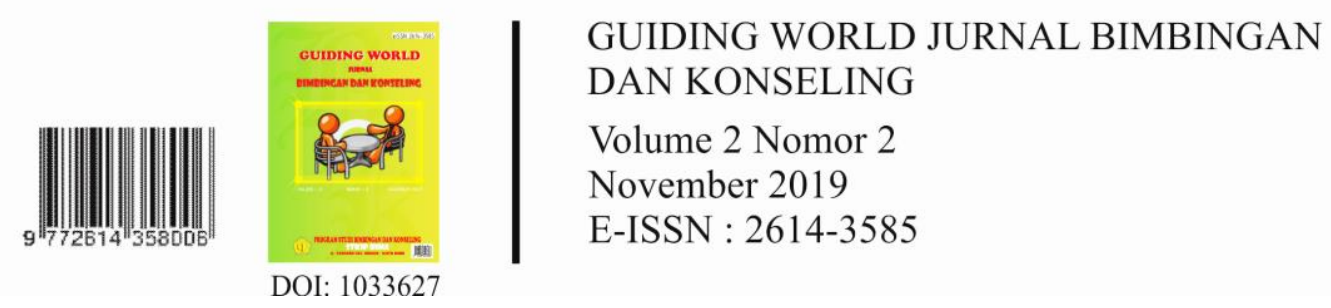

Nilai estetika adalah nilai keindahan yang terdapat dalam sebuah karya sastra baik dalam bentuk fisik maupun dalam bentuk lisan, misalnya bentuk motif, sajak, pilihan kata, nada dan intonasinya.

\section{g. Nilai Pendidikan}

Nilai pendidikan adalah hal-hal yang berkaitan dengan dunia pendidikan, yaitu segala sesuatu yang dapat dipetik sebagai penambahan ilmu pengetahuan/pendidikan kita sehingga pembaca atau pendengar dapat mengoreksi diri dengan menyadari apa yang pernah dilakukan.

Makna adalah maksud pembicara, penulis, atau pengertian yang diberikan pada suatu bentuk kebahasaan (KBBI, 1991: 619). Nilai atau makna yang dianalisis dalam Nggahi Ncemba adalah nilai atau makna yang tersirat di balik makna kata (makna yang sebenarnya). Proses analisis makna ini dilakukan setelah data yang diperoleh diterjemahkan ke dalam bahasa Indonesia.

\section{Metode Penelitian}

Penelitian ini merupakan jenis penelitian empiris dengan menggunakan metode deskriptif kualitatif. Metode deskriptif kualitatif adalah metode yang menggambarkan suatu masalah dengan kata-kata serta dipisahkan menurut kategori untuk memperoleh kesimpulan (dalam Arikunto, 1993:207).

Penelitian ini berlokasi di wilayah Kecamatan Sape Kabupaten Bima. Pemilihan lokasi penelitian ini berdasarkan pertimbangan bahwa masih dijumpai adanya penutur yang masih menggunakan dan mengetahui serta mengerti Nggahi Ncemba.

Sumber data adalah masyarakat penutur bahasa Bima (Nggahi Mbojo) yang berdomisili di wilayah Kecamatan Sape Kabupaten Bima. Jumlah Desa di Kecamatan Sape sebanyak 17 desa dengan jumlah penduduk sebanyak 56.326 jiwa. Sampel dalam penelitian ini adalah perwakilan masyarakat Kecamatan Sape yang diambil secara acak dari tiaptiap desa (masing-masing dua orang tiap desa). Cara menentukannya adalah dengan menggunakan teknik acak atau random sampling, sehingga jumlah responden yang dikenai sampel sebanyak 34 orang. Kriteria yang harus dimiliki oleh sampel yang menjadi responden atau informan dalam penelitian ini harus memenuhi syarat sebagai berikut.

1) Informan berjenis kelamin pria atau wanita.

2) Informan merupakan masyarakat asli di wilayah penelitian.

3) Berusia antara 17-60 tahun (tidak pikun).

4) Minimal berpendidikan SD.

5) Pekerjaan petani, buruh atau yang lainnya (bukan PNS).

6) Bisa berbahasa Indonesia.

7) Informan memiliki daya ingat yang baik.

8) Sehat jasmani dan rohani.

9) Mengetahui dan mengerti Nggahi Ncemba.

Teknik pengumpulan data menggunakan teknik observasi, teknik wawancara, teknik rekaman, teknik transkripsi dan terjemahan. Adapun 
dalam menganalisis data menggunakan teknik deskriptif kualitatif, yaitu teknik yang digunakan untuk menggambarkan suatu masalah dengan narasi tanpa menggunakan angka seperti penelitian kuantitatif dan berusaha menganalisis data secara sistematis serta dipisahkan menurut kategori untuk memperoleh kesimpulan. Langkah-langkah dalam menganalisi data ini yaitu identifikasi, transkripsi, klasifikasi, dan evaluasi. Dengan menggunakan teknik analisis data ini, diharapkan dapat diperoleh gambaran tentang bentuk, fungsi dan nilai Nggahi Ncemba yang hidup dan berkembang dalam masyarakat Bima di Kecamatan Sape Kabupaten Bima.

\section{Hasil Penelitian dan Pembahasan}

\section{Hasil Penelitian}

Berdasarkan hasil penelitian yang dilakukan peneliti di Kecamatan Sape Kabupaten Bima diperoleh data dari sejumlah informan (sumber informasi). Data yang dimaksud adalah Nggahi Ncemba yang hidup dan berkembang dalam masyarakat Bima di Kecamatan Sape Kabupaten Bima sebagai berikut.

1. Aina ca'u ntanda sa ese

Terjemahannya: Jangan suka melihat ke atas

2. Aina imbi weki

Terjemahannya: Jangan percaya diri

3. Aina kamaru mada ro kamidi ade, linggapu sadumpu nepi pu rui bada. Terjemahannya: Janganlah menidurkan mata dan mendiamkan hati, berbantallah kayu sepotong berkasurlah duri kaktus.

4. Aina kani ilmu bi'a o'o, ma ese di hanta ma awa di tonda

Terjemahannya: Jangan pakai ilmu belah bambu, yang atas diangkat, yang bawah diinjak

5. Aina kani ilmu sanggilo

Terjemahannya: Jangan pakai ilmu ikan gabus

6. Aina pana ponda kalea sungga

Terjemahannya: Jangan panas seperti panasnya buah labu dan menyala seperti menyalanya merang

7. Aina mapu bune keto sahe Terjemahannya: Jangan lemas seperti ekor sapi

8. Arujiki jimba wati loa raka ba mbe'e

Terjemahannya: Rejekinya domba tidak bisa didapat oleh kambing

9. $\quad$ Ba ra kakanda nggomi, di katako kai nahu

Terjemahannya: Karena engkau yang mulai berkotek, maka aku berkotek juga

10. Bune janga ma ma $\underline{b} u$ ana

Terjemahannya: Seperti ayam yang jatuh anak

11. Maja labo dahu

Terjemahannya: Malu dan takut

12. Dodopu tando ro tambari kontu 
Terjemahannya: Pandang kebawah, depan dan menoleh kebelakang

13. Eda mbuda, ringa mpinga

Terjemahannya: Lihat buta, dengar tuli

14. Edera nahu, sura dou labo dana

Terjemahannya: Tidak usah saya, asal orang lain dengan tanah

15. Edera nggahi di lenga, ponda ndai ma lengi

Terjemahannya: Jangan bilang pada kawan labu sendiri yang bocor

16. Hambu tembe kantea tando ndai

Terjemahannya: Mengangkat sarung kelihatan kemaluan sendiri.

17. Hi'i sanggi'i, peke satako

Terjemahannya: Daging sekerat, tulang sebatang

18. Ilana made, wati si ou ba made

Terjemahannya: Tidak akan mati, tidak terpanggil oleh mati

19. Imbi ana sama labo dou ma mbuda sabae, imbi dou sama labo dou ma mbuda rapu

Terjemahannya: Percaya anak sama dengan orang yang buta sebelah, percaya orang sama dengan orang yang buta rapat.

20. Karoci ma taho kangeri ma iha

Terjemahannya: Mempercepat yang baik, memperlambat yang jelek

21. Kese tahopu dua, dua tahopu tolu

Terjemahannya: Satu lebih baik dua, dua lebih baik tiga

22. Likipu loko ndaimu

Terjemahannya: Cubitlah perut dirimu sendiri

23. Maja kai nggahi mataho

Terjemahannya: Malu mendengar kata yang baik

24. Ma lampasi wara di malempi, ma keha si wara di kohi

Terjemahannya: Kalau berjalan ada yang membantu, kalau mengais ada yang digali

25. Malanta labompa dicua dula labo

Terjemahannya: Kain putih saja yang masing-masing di bawah

pulang

26. Mandukusi sawa aina di mpoka kaina mbobo ra mbala kai dana

Terjemahannya: Bila memukul ular jangan patah cambuk dan

berbekas di tanah

27. Mantiri nggahi karongga, mabisa nggahi paresa

Terjemahannya: Yang lurus kata menyampaikan, yang bertuah kata periksa

28. Mbolo ro dampa ma katantuna rawi

Terjemahannya: Bulat dan rata yang menentukan pekerjaan

29. Mpore wati, tahopu mpeke wara

Terjemahannya: Gemuk tidak, lebih baik adanya kurus

30. Mu kado ti ngawa na kanggado, mukinda ti ngawa na kangginda, mu wongge ku woja na tambongge 


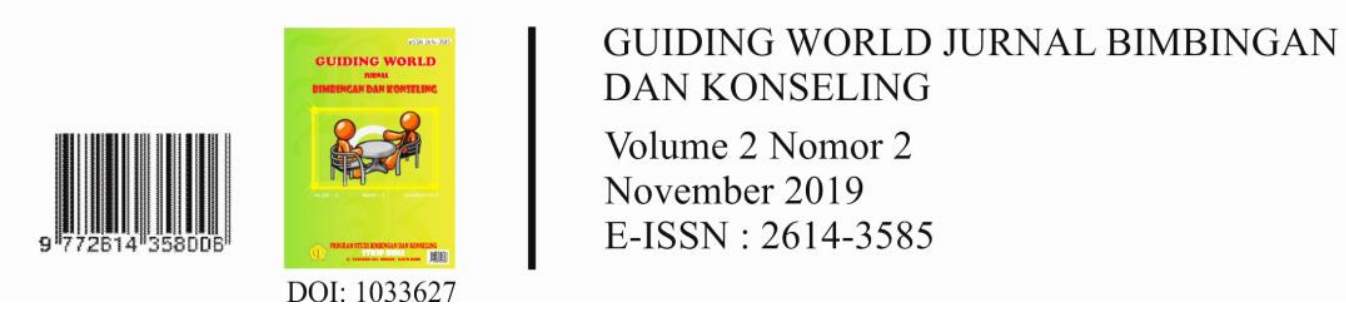

Terjemahannya: Digerakkan tidak mau bergerak, diguncangkan tidak berguncang, dicabut pantang tercabut

31. Na to'i si angi hintipu aina, na na'e si angi co'o pu aina.

Terjemahannya: Kalau kecil angin tariklah talinya, kalau besar angin lepaslah talinya

32. Nawa ma kakimbi diru'u ita rumaku

Terjemahannya: Nyawaku yang berdenyut diperuntukkan bagi tuanku

33. Ncao huni labo afu

Terjemahannya: Bertemu kunyit dengan kapur sirih

34. Nggahi rawi pahu

Terjemahannya: Berkata, berkarya hendaklah menghasilkan kenyataan

35. Ncao kaka labo puru

Terjemahannya: Bertemu lubang pahatan dengan purus

36. Nggomi ampode masepe sampa, nahu ipa baera

Terjemahannya: Engkau baru pinjam sampan saya sudah di seberang

37. Nu'u wadu si namimi, nu'u wolo si nakarente

Terjemahannya: Turunan batu akan tenggelam, turunan kapas akan terapung

38. Paki ponggo, sarinci tobe pingga

Terjemahannya: Buang kapak, memungut pecahan piring

39. Ruku ampo wara diraka, lampa ampo wara dimalempi

Terjemahannya: Gerak baru ada diperoleh, jalan baru ada yang menopang

40. Rungka ra sake tahopu nono racu

Terjemahannya: Merubah janji lebih baik minum racun

41. Raba dou si loaku eda, raba ndai tiloa eda

Terjemahannya: Pagar orang dapat dilihat, pagar sendiri tidak dapat dilihat

42. Samenana ra parenta kai, su'u kai pu tuta, lemba kai pu dinca

Terjemahannya: Semuanya yang diperintahkan dijunjung dengan

43. Simi di oi ma tendo kepala, pikul dengan bahu

Terjemahannya: Menyelam di air yang dangkal

44. Tukipu peke, sepapu sanggeremu

Terjemahannya: Topanglah tulang, belahlah rusukmu

45. Uluku nemba guru, kentoku nemba ruma

Terjemahannya: Lebih dahulu aku menyembah guru, kemudian aku menyembah Tuhan (Allah)

46. Wati wara nata kai ba nahi, mpaha kai ba afu

Terjemahannya: Tidak ada pedisnya seperti sirih dan kapur sirih

47. Wati loa dicengga, mada me'e mpa mada bura

Terjemahannya: Tidak dapat dibagi, mata hitam dan mata putih

48. Wa'u si ra sama ta cua liwa simi 


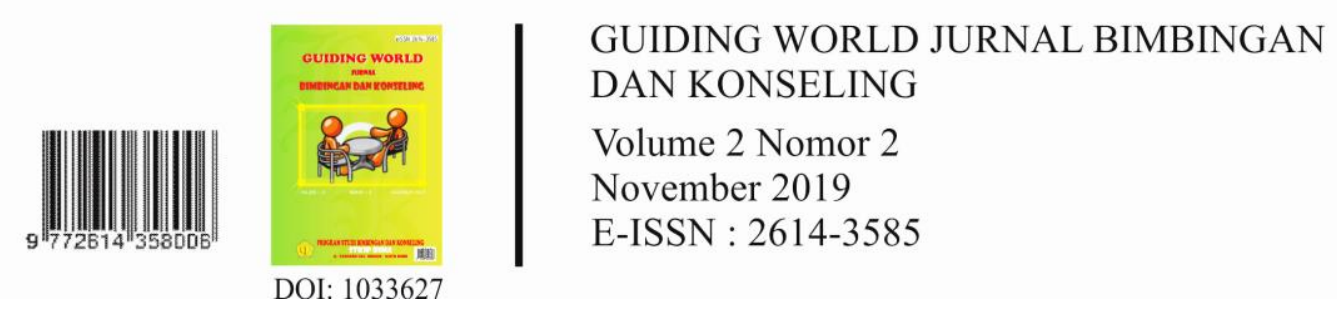

Terjemahannya: Kalau sudah bersama-sama, masing-masing

49. Weli sahe ade ndano berenang dan menyelam

Terjemahannya: Beli kerbau di dalam kubangan

50. Bune Eja labo Ntala

Terjemahannya: Seperti Birah dengan Keladi

\section{Analisis Data}

Nggahi Ncemba pada masyarakat Bima di Kecamatan Sape Kabupaten Bima ini diklasifikasikan dalam beberapa bentuk sebagai berikut.

\section{a. Pepatah}

Pepatah adalah kelompok kata atau kalimat yang digunakan orang untuk mematahkan perbuatan atau perbincangan orang. Pepatah dalam bahasa Indonesia sama bentuk dan maksudnya dengan Nggahi Ncemba. Hal ini dibuktikan dengan Nggahi Ncemba di bawah ini.

a. Dodopu tando ro tambari kontu

Terjemahannya : Pandang ke bawah, depan dan menoleh kebelakang

b. Malanta la ba mpa dicua wa'a dula labo

Terjemahannya: Kain putih saja masing-masing dibawa pulang

c. Ruku ampo wara di raka lampa ampo wara ma lempi

Terjemahannya : Gerak baru ada yang diperoleh, jalan baru ada yang menopang

Merujuk contoh di atas, dapat dikatakan bahwa bentuk Nggahi Ncemba sama dengan pepatah seperti kalimat pertama "Dodopu tando ro tambari kontu". Bentuk Ngghi Ncemba ini termasuk kelompok kata atau kalimat untuk mematahkan perbuatan seseorang yang menganggap dirinya saja yang paling benar, dan selalu meremehkan orang lain. Maksud dari bentuk Nggahi Ncemba ini adalah mengukur kemampuan diri dalam bergaul, jangan suka menyombongkan diri dan membanggakan diri. Sedangkan Nggahi Ncemba yang kedua juga mematahkan perbuatan orang yang dalam hidupnya hanya mengumpulkan harta benda tanpa mau beramal. Maksud ungkapan ini adalah diharapkan menusia harus ingat bahwa hidup ini bukan hanya digunakan untuk kehidupan dunia. Kehidupan dunia beleh dikejar tetapi urusan akhirat jangan dilupakan.

Begitu juga bentuk Nggahi Ncemba yang ketiga, yaitu untuk mematahkan perbuatan orang yang malas bekerja dan tidak mau berusaha. Maksud nggahi Ncemba ini bahwa segala sesuatu baru bisa diperoleh kalau kita berusaha dan bekerja karena tidak ada sesuatu yang datang dengan sendirinya tanpa kita usahkan dan kita cari. Bentuk ungkapan ini menggambarkan bahwa orang yang bergerak dan berjalan untuk memperoleh sesuatu.

\section{b. Perumpamaan}

Perumpamaan adalah menbandingkan dua hal yang pada hakikatnya berbeda dengan harapan, biasanya menggunakan kata bagai, seperti, umpama, 


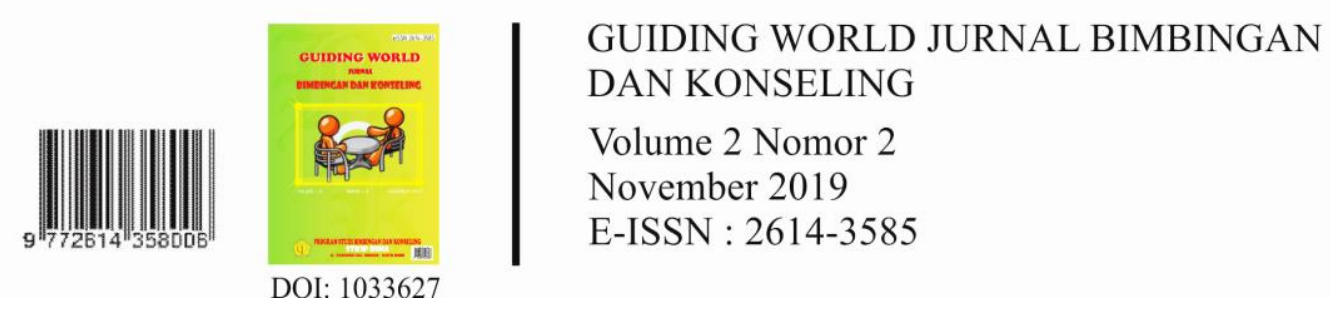

ibarat, dan laksana. Perummpamaan ini identik dengan Nggahi Ncemba dalam bahasa Bima karna Ngghi Ncemba juga menggunakan kata seperti. Hal ini dibuktikan dengan contoh Ngghi Ncemba di bawah ini.

a. Bune janga ma mabu ana.

Terjemahannya: Seperti ayam yang jatuh anak.

b. Aina mapu bune keto sahe.

Terjemahannya: Jangan lemas seperti ekor sapi.

Bentuk Nggahi Ncemba di atas merupakan bentuk perumpamaan

karena Nggahi Ncemba menggunakan kata Bune "Seperti" untuk membandingkan. Pada Nggahi Ncemba yang pertama kata-kata janga ma mabu ana "ayam yang jatuh anak" dijadikan sebagai perbandingan. Maksud dari Nggahin Ncemba ini adalah keramahtamahan dalam menyambut tamu dan penuh rasa kekeluargaan dalam bergaul.

Sedangkan Nggahi Ncemba yang kedua kata Bune "seperti" yang disandinngkan dengan kata Keto Sahe sebagai bahan perbandingan. Jadi perbandingan ini terjadi karena adanya perbuatan atau perilaku yang menyerupai benda atau makhluk tersebut.

\section{c. Pemeo}

Pemeo adalah ejekan (olok-olokkan) yang menjadi buah bibir orang, perkataan yang lucu (untuk menyindir). Pameo ini hampir sama bentuk dan maksudnya dengan ungkapan Nggahi Ncemba dalam bahasa Bima. Nggahi Ncemba yang bersifat olokan tidak hanya sebatas mengolok orang, namun bentuk Nggahi Ncemba ini kedengaran liriknya mengolok tetapi ada maksud baik didalamnya sebab imbas dari olokan ini dapat membuat orang sadar akan kesalahan dan malu untuk mengulanginya. Hal ini dapat dibuktikan dengan Nggahi Ncemba dibawah ini.

a. Raba dou si loa ku eda, raba ndai tiloa eda

Terjemahannya: Pagar orang dapat dilihat, pagar sendiri tidak dapat dilihat.

b. $\underline{B}$ a ra kakanda $\underline{\text { b}}$ a nggomi di katako kai $\underline{\text { ba }}$ nahu Terjemahannya: Karena engkau yang mulai berkotek maka aku
berkotek

Bentuk Nggahi Ncemba yang pertama merupakan sindiran kepada orang yang suka mengoreksi kesalahan orang lain, yang tidak sadar kalau dia sendiri melakukan kesalahan yang sama. Penggunaan Nggahi Ncemba ini ditujukan kepada seseorang yang menyindir orang lain agar menyadari kesalahannya sendirinya dan mau berubah sehingga tidak lagi mengoreksi diri orang lain, melainkan dia mengoreksi dirinya sendiri.

Sedangkan bentuk Nggahi Ncemba yang kedua digunakan untuk menyindir dua orang yang berselisih, kemudian saling membuka keaiban masing-masing. Karena yang satu telah membeberkan rahasia atau keaiban, maka yang lain juga membalas dengan membuka pula keaiban lawannya. Maksud dari ungkapan ini adalah ajaran agar orang jangan membeberkan aib orang lain. Karena sebagai manusia pasti punya kelemahan atau pernah berbuat yang tidak baik. Juga karena perbuatan yang membeberkan orang 
lain itu merupakan pekerjaan dosa. Jadi, kalau memang ada orang lain yang berbuat salah lebih baik kita berusaha menasehati.

\section{d. Pribahasa}

Pribahasa adalah kelompok kata atau kalimat yang biasanya berisi maksud tertentu, kadang-kadang berisi nasehat, prinsip hidup, atau aturan tingkah laku. Begitu juga Nggahi Ncemba dalam bahasa Bima sama halnya dengan bentuk pribahasa Indonesia. Hal ini dapat dibuktikan dengan Nggahi Ncemba di bawah ini.

a. Nggahi rawi pahu

Terjemahannya: Berkata hendaknya dibuktikan dengan hasil karya yang nyata (apa yang dikatakan harus dibuktikan)

\section{b. Ede ra nahu, sura dou labo dana}

Terjemahannya: Tidak usah aku, asal orang dengan tanah

Bentuk Nggahi Ncemba di atas mutlak menjadi prinsip hidup dan semboyan bagi masyarakat Bima di Kecamatan Sape Kabupaten Bima khususnya, bahkan bagi masyarakat Bima pada umumnya. Seperti bentuk Nggahi Ncemba yang pertama Nggahi rawi pahu ini merupakan bentuk semboyan atau prinsip hidup bagi masyarakat biasa maupun para pemimpin karena dengan ungkapan ini akan menimbulkan kepercayaan dari masyarakat yang dipimpinnya. Maksud Nggahi Ncemba ini adalah satunya kata dengan perbuatan. Suatu ungkapan harus direalisasikan dengan perbuatan sehingga mencapai suatu hasil. Seseorang harus berpegang teguh pada ucapannya, tidak membual dan omong kosong. Ungkapan ini bisa juga dijadikan alat untuk mengkritik seseorang, lembaga, atau pemimpin untuk mengingatkan terhadap sesuatu yang telah diucapkannya.

Bentuk Nggahi Ncemba yang kedua juga merupakan prinsip hidup. Ungkapan ini mengandung petuah agar kita selalu mengutamakan kepentingan umum di atas kepentingan pribadi dan golongan. Kata Dou dan Dana mengacu kepada orang banyak dan negara. Jadi kepentingan umum atau orang banyak selalu didahulukan, kepentingan diri sendiri, golongan tertentu, keturunan dan keluarga tertentu seyogyanya dinomorduakan.

\section{Pembahasan}

Berdasarkan analisis data, maka Nggahi Ncemba ini perlu dijabarkan fungsi dan nilai yang terkandung di dalamnya. Seperti karya sastra lainnya Nggahi Ncemba memiliki fungsi dan nilai bagi masyarakat penggunanya, sebagai berikut.

\section{Fungsi dan Nilai Religi}

Nggahi Ncemba memiliki fungsi dan nilai religi ialah nilai-nilai yang berhubungan antara manusia dan Tuhan-Nya, sehingga Nggahi Ncemba yang mengandung fungsi dan nilai religi ini dapat memberikan suri taula dan bagi kehidupan masyarakat penggunanya untuk selalu menahan diri dari perbuatan-perbuatan tercela dan dapat melaksanakan kewajibannya sebagai makhluk yang beragama. Fungsi dan nilai yang bersifat religi 69 


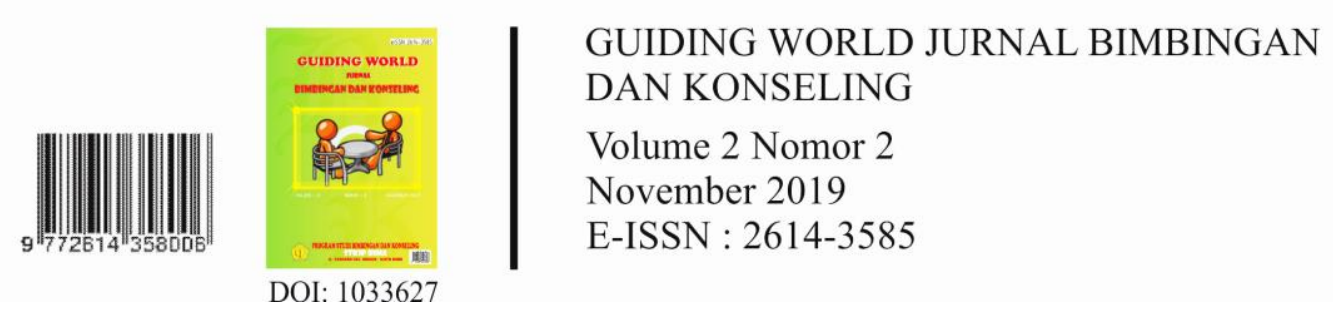

tersebut terkandung dalam Nggahi Ncemba berikut ini.

a. Aina ca'u ntanda sa ese

Nggahi Ncemba ini mengandung makna sebagai larangan, agar jangan membandingkan diri kita dengan keadaan orang lain yang lebih baik dari diri kita, sehingga kita merasa kecil, bodoh, miskin, dan sebagainya. Karena keadaan yang demikian cenderung membuat hal-hal yang tercela.

b. Arujiki jimba wati loa raka ba mbe'e

Nggahi Ncemba ini mengandung makna bahwa setiap orang mempunyai rejeki masing-masing. Dalam ungkapan ini diumpamakan seperti domba dan kambing. Walaupun keduanya makan dalam satu kandang, masingmasing memperoleh kekenyangan sendiri, sesuai dengan cara masingmasing memakan makanan dalam kandang tesebut.

c. Ila na made, wati si ou ba made

Nggahi Ncemba ini mengandung makna, bahwa mati itu diluar kemauan manusia untuk menentukannya, melainkan sepenuhnya ada ditangan tuhan. Apabila ajal sudah datang, tidak akan dapat ditunda sedikit pun. Sebaliknya bila ajal belum tiba, maut itu tidak akan datang. Oleh karena itu, manusia harus berserah diri sepenuhnya kepada Tuhan. Dalam arti yang lebih luas, Nggahi Ncemba ini mengandung arti bahwa segala yang menimpa manusia itu semata-mata takdir Tuhan.

d. Malanta labo mpa dicua dula labo

Nggahi Ncemba ini mengandung peringatan bahwa kita kalau meninggal kelak hanya kain putih yang menemani kita ke alam kubur. Nggahi Ncemba ini mengandung ajaran agar kita jangan menumpuk harta secara berlebih-lebihan dan jangan sampai kita diperbudak oleh harta itu. Jangan pula harta yang berlebihan itu kita nikmati sendiri sementara orang lain di sekitar kita kelaparan, dan jangan pula kita melupakan kehidupan kelak di akhirat, karena kita asyik mengumpulkan dan menikmati kehidupan dunia.

\section{Fungsi dan Nilai Pendidikan}

Nggahi Ncemba memiliki fungsi dan nilai pendidikan yaitu hal-hal yang berkaitan dengan dunia pendidikan, yaitu segala sesuatu yang dapat dipetik sebagai penambahan ilmu pengetahuan sehingga pembaca atau pendengar dapat mengoreksi diri dengan menyadari apa yang pernah dilakuakan. Untuk lebih jelasnya, fungsi dan nilai pendidikan yang terkandung dalam Nggahi Ncemba dideskripsikan pada contoh berikut ini.

a. Imbi ana sama labo dou mambuda sabae, imbi dou sama labo dou mambuda rapu

Nggahi Ncemba ini mengandung makna agar kita selalu waspada dan berhati-hati terhadap siapa pun bahkan anak kita sendiri sekali pun. Jangan terlalu cepat percaya atau menerima, tetapi teliti dulu dengan baik. Dengan Nggahi Ncemba ini mempercayai anak sendiri 


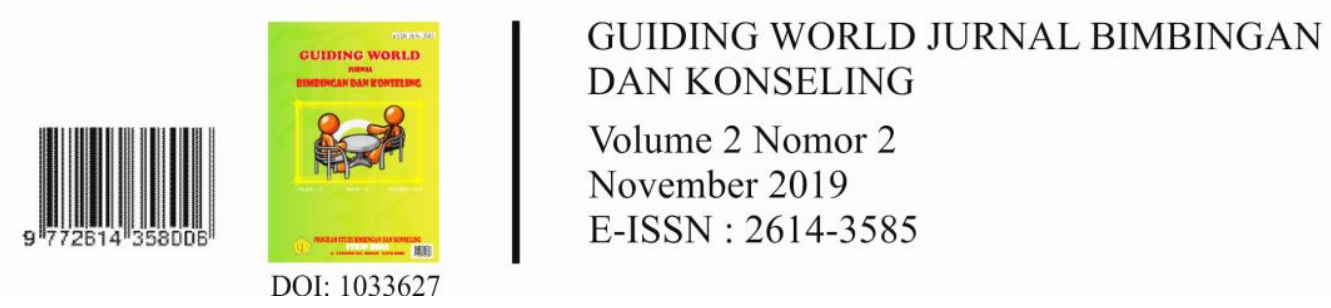

diumpamakan sebagai mbuda mada sabae atau (buta mata sebelah), maksudnya janganlah kita percaya sepenuhnya walaupun kepada anak kita sendiri. Perumpamaan berikutnya dinyatakan mbuda rapu (buta total). Kalau kita mempercayai orang lain sepenuhnya diibaratkan kita buta total. Maksudnya kalau kepada anak sendiri saja kita tidak boleh cepat-cepat memberikan kepercayaan penuh, apalagi kepada orang lain. Oleh karena itu, kepada orang lain justru kita harus lebih berhati-hati.

b. Karoci ma taho kangeri ma iha

Nggahi Ncemba ini mengandung makna untuk segera melaksanakan halhal yang baik, karena siapa tahu tidak ada kesempatan, atau akan banyak halangan apabila ditunda melakukannya. Sebaiknya pekerjaan yang jelek jangan segera dilakukan, karena dengan penundaan itu kita mungkin sadar kembali akan akibatnya sehingga terhindar dari perbuatan jelek itu.

c. Maja kai nggahi mataho

Makna yang terkandung dalam Nggahi Ncemba ini ialah malu dengan tutur kata yang baik, atau malu dengan nasehat yang baik. Maksudnya apabila diberi nasehat yang baik, maka malu untuk melalukan perbuatan yang tidak baik, atau malu melanggar nasehat itu. Nggahi Ncemba ini mengandung ajaran budi pekerti yang baik, yaitu agar kita hendaknya merasa malu mengerjakan hal yang tidak baik, lebih-lebih setelah mendengar kata nasehat.

d. Paki ponggo sarinci tobe pingga

Nggahi Ncemba ini mengandung makna, bahwa menyia-nyiakan yang baik malahan mendapatkan yang jelek. Dalam Nggahi Ncemba ini sesuatu yang baik diumpamakan sebagai kapak. Kapak adalah alat yang sangat bermanfaat bagi kita, sedangkan pecahan piring adalah barang yang tidak bermanfaat.

e. Samenana ra parenta kai, su'u kai pu tuta, lemba kaipu lipi

Nggahi Ncemba ini mengandung makna kedisiplinan melaksanakan suatu tugas dengan penuh tanggung jawab, atau semua tugas yang diberikan kepada kita dan telah kita terima hendaknya dilaksanakan dengan penuh tanggung jawab.

f. Ulu kunemba guru, kento kunemba ruma

Nggahi Ncemba ini mengandung makna bahwa orang yang baik/murid yang baik adalah orang/murid yang taat kepada Allah dan hormat kepada gurunya. Karena gurulah yang mendidik seseorang sampai mengenal Allah. Orang yang menyembah Allah SWT. tetapi melupakan gurunya dianggap sebagai sikap yang tercela.

\section{Fungsi dan Nilai Moral}

Fungsi dan nilai moral atau sering pula disebut akhlak dalam karya sastra tentunya dapat mengajak dan mendidik masyarakat penggunanya untuk menjadi manusia yang berbudi luhur dan bermoral tinggi, sehingga dapat hidup di tengah masyarakat dan dunia pada umumnya. Fungsi dan nilai moral yang terkandung dalam bentuk nggahi ncemba ini sebagai 


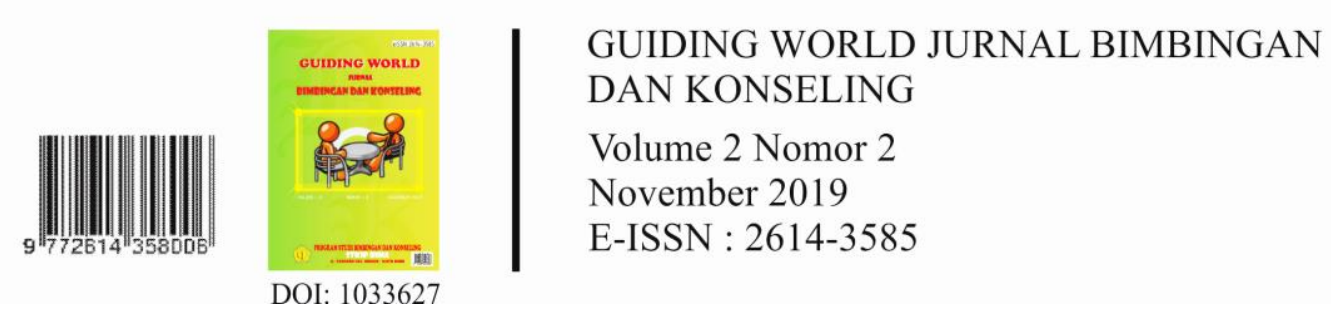

berikut.

a. Aina imbi weki

Nggahi Ncemba ini mengandung peringatan, agar kita jangan menonjolkan diri secara berlebihan, apalagi sampai menyombongkan diri. Oleh karena itu, ungkapan ini lebih bersifat nasehat, agar jangan terlalu menyombongkan diri.

b. Aina kani ilmu sanggilo

Nggahi Ncemba ini mengandung makna melarang mencelakakan teman, atau anak buah. Orang yang suka mencelakakan teman atau anak buah sendiri diibaratkan sebagai ikan gabus, karena kebiasaan ikan gabus adalah memakan anaknya sendiri.

c. Dahu la'o maja atau Maja labo dahu

Nggahi Ncemba ini mengandung makna agar orang selalu takut kepada Allah, dan malu kepada sesama manusia. Kita tidak boleh takut kepada sesama manusia, kita hanya boleh takut kepada Allah. Takut kepada sesama manusia dalam arti sikap yang malu.

d. Bune janga ma mabu ana

Nggahi Ncemba ini mengandung makna keramahtamahan dalam menyambut tamu. Dalam Nggahi Ncemba ini digambarkan dengan tingkah laku ayam yang mendapatkan anak, biasanya si induk ayam selalu berkotek kesana-kemari sambil mengais-ngaiskan kakinya ke tanah sebagai isyarat memanggil anaknya untuk diberi makan. Nggahi Ncemba ini disampaikan sebagai anjuran, hendaknya kita selalu bersikap ramah-tamah dan penuh rasa kekeluargaan dalam bergaul.

e. Dodopu tando ro tambari kontu

Nggahi Ncemba ini mengandung makna agar manusia mengukur kemampuan diri dalam bergaul. Jangan suka menyombongkan diri dan membanggakan diri. Nggahi Ncemba ini mengandung ajaran agar orang selalu mawas diri, tenggang rasa terhadap orang lain, lebih-lebih terhadap kehidupan bermasyarakat.

f. Hambu tembe kantea tando ndai

Nggahi Ncemba ini mengandung makna membuka keaiban orang lain, sama dengan membuka keaiban diri sendri. Sebab tentu saja orang lain yang merasa dirugikan karena rahasianya dibuka, dengan sendirinya ia akan membalas membuka rahasia orang yang telah membuka rahasianya. Dalam Nggahi Ncemba ini diibaratkan dengan hambu tembe. Hambu tembe adalah gerakan mengangkat-angkat sarung yang sedang dipakai. Secara tidak disadari mungkin saja mengangkatnya terlalu tinggi hingga kemaluanya akan tampak. Padahal kemaluan adalah milik yang harus disembunyikan agar tidak nampak oleh orang lain. Hambu tembe diibaratkan sebagai membuka rahasia orang lain. 


\section{g. Rungka ra sake taho pu nono racu}

Ngagahi Ncemba ini mengandung makna bahwa apabila telah membuat janji hendaknya ditepati. Apabila kita telah bersepakat hendaklah kesepakatan itu dilaksanakan dengan penuh tanggung jawab.

h. Makado tingawana kanggado, makinda tingawana kangginda, mawonggeku wati tambonggena

Nggahi Ncemba ini mengandung makna jika kita menjadi seorang pemimpin hendaknya mampu menjadi pemimpin yang dipercaya karena jujur, adil, dan disiplin. Oleh karena itu diumpamakan sebagai tiang yang ditancapkan, biar digerakkan, digoncang bahkan dicabut pun tidak akan tercabut karena kokohnya.

i. Nggahi rawi pahu

Makna yang terkandung dalam Nggahi Ncemba ini ialah satunya kata dengan perbuatan. Berkata harus diikuti dengan kerja dan bekerja harus sampai memperoleh hasil. Tidak hanya merupakan kata-kata muluk saja.

\section{Fungsi dan Nilai sosial}

Fungsi dan nilai sosial adalah hal-hal yang penting atau berguna bagi kemanusiaan dalam hubungan kemasyarakatan, terutama dalam hubungannya dengan tolong menolong, dan hidup berdampingan dengan penuh asah, asih, dan asuh, sebagaimana fungsi dan nilai sosial yang terkandung dalam Nggahi Ncemba berikut ini.

a. Edera nahu, sura dou labo dana

Nggahi Ncemba ini mengandung petuah agar kita selalu mengutamakan kepentingan umum di atas kepentingan pribadi dan golongan. Dalam Nggahi Ncemba ini digunakan kata-kata dou labo dana artinya "orang dengan tanah". Kata dou di sini mengandung arti "orang banyak" (rakyat). Sedangkan kata dana mengandung arti "Negeri" atau negara. Dalam penggunaan sehari-hari artinya sudah diperluas, yaitu dikatakan kepada seseorang yang selalu memperhatikan kepentingan rakyat.

b. Kese tahopu dua, dua tahopu tolu

Nggahi Ncemba ini mengandung makna, bahwa bekerjasama dalam menyelesaikan sesuatu pekerjaan lebih baik daripada mengerjakannya sendiri-sendri. Dengan bekerjasama maka pekerjaan akan menjadi lebih ringan dan lebih mudah diselesaikan.

Nggahi Ncemba ini mengandung ajaran bahwa persatuan dan kegotongroyongan adalah sesuatu yang mulia, dengan persatuan dan kegotongroyongan pekerjaan akan mudah diselesaikan, permasalahan akan mudah dipecahkan, dan hasilnya lebih memuaskan.

c. Mandukusi sawa aina di mpoka kaina wobo mbala kaina dana Nggahi Ncemba ini mengandung makna bahwa dalam menghadapi persoalan harus bijaksana, sehingga apa yang kita inginkan tercapai, tanpa ada pihak-pihak lain yang dirugikan.

\section{d. Nawa ma kakimbi diru'u ita rumaku}




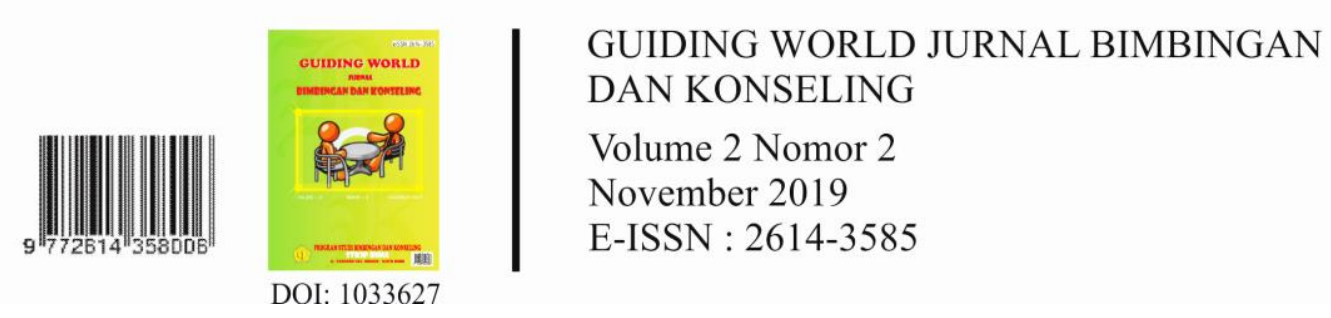

Makna yang terkandung dalam Nggahi Ncemba ini ialah pernyataan kesetiaan kepada raja/pimpinan. Kesetiaan tersebut digambarkan dengan kerelaan berkorban bagi raja/pemimpin sekali pun nyawa menjadi taruhannya.

e. Wati wara nata kai ba nahi, mpaha kai ba afu

Nggahi Ncemba ini mengandung makna kehidupan yang akrab, rukun. seia-sekata, dan tidak pernah terjadi perselisihan. Dalam Nggahi Ncemba ini digambarkan sebagai orang makan sirih, antara rasa siri dan rasa kapur siri sudah menjadi satu, tidak dapat dibedakan rasanya satupersatu.

f. Wa'u si ra sama ta cua liwa simi

Nggahi Ncemba ini mengandung makna, yaitu kalau kita sudah bersepakat melakukan suatu tindakan, perbuatan, atau pekerjaan bagaimana pun akibatnya harus ditanggung bersama-sama.

\section{Fungsi dan Nilai Ekonomi}

Fungsi dan nilai ekonomi adalah hal-hal yang menjadi taradisi masyarakat sebagai semboyan dalam mencari nafkah atau penghasilan tambahan untuk memenuhi kebutuhan sehari-hari dengan jalan yang baik. Untuk lebih jelasnya, fungsi dan nilai ekonomi yang terkandung dalam Nggahi Ncemba dideskripsikan pada contoh berikut ini.

a. Aina kamaru mada ro kamidi ade, linggapu sadumpu nepipu rui bada Nggahi Ncemba ini mengandung makna larangan bermalas-malasan sekaligus anjuran untuk bekerja keras.

b. Ma lampasi wara di malempi, ma keha si wara di kohi

Nggahi Ncemba ini mengandung makna bahwa setiap usaha pasti akan membuahkan hasil. Dalam Nggahi Ncemba ini digunakan perumpamaan lampa (berjalan) yang berarti menggunakan/ memanfaatkan kaki untuk berjalan. Sedang kehasi (mengais) adalah perumpamaan daripada penggunaan tangan untuk bekerja. Keduanya berarti bahwa tangan dan kaki harus bekerja, tidak bermalas-malasan.

c. Tukipu peke sepapu sanggeremu

Nggahi Ncemba ini mengandung makna ajakan untuk bekerja keras. Dalam Nggahi Ncemba ini digunakan kata peke yang berarti tulang, dan sanggere yang berarti rusuk. Sebab kalau kita sedang bekerja mengangkat barang-barang yang berat kita ditopang oleh tulang yang kuat, dan rusuk pun terasa tegang seolah-olah terbelah. Sehingga ajakan bekerja keras diibaratkan sebagai menopang tulang dan membelah rusuk.

d. Weli sahe ade ndano

Nggahi Ncemba ini bermakna agar berhati-hati dalam bertindak agar jangan merugi. Dalam Nggahi Ncemba ini diibaratkan kita membeli kerbau yang tidak dapat dilihat tubuhnya secara lengkap, karena kerbau 


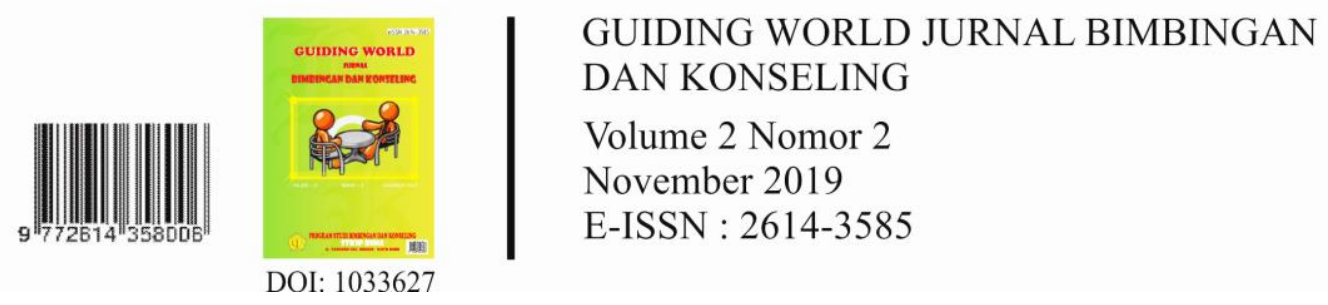

itu berada dalam danau. Mungkin yang kelihatan hanya punggungnya, atau kepalanya saja sehingga tidak dapat kita ketahui, apakah kerbau itu gemuk atau kurus. Ini berarti kita membeli sesuatu yang tidak jelas atau belum diketahui pasti keadaan yang sebenarnya.

\section{PENUTUP}

\section{Simpulan}

Berdasarkan hasil penelitian dan pembahasan, maka penelitian ini dapat disimpulkan, sebagai berikut.

1. Bentuk Nggahi Ncemba pada masyarakat Bima di Kecamatan Sape Kabupaten Bima ada empat macam bentuk, yaitu dalam bentuk pepatah, perumpamaan, pemeo, dan pribahasa. Walaupun bentuknya berbeda-beda namun semua bentuk tersebut dikategorikan sebagai Nggahi Ncemba.

2. Fungsi dan nilai yang terkandung dalam Nggahi Ncemba, yaitu fungsi dan nilai religi, pendidikan, moral, sosial dan ekonomi.

3. Nggahi Ncemba sampai saat ini masih hidup pada masyarakat Bima di Kecamatan Sape Kabupaten Bima.

\section{Saran}

Mengacu pada simpulan di atas, maka hasil penelitian ini dapat disarankan kepada:

1. Masyarakat Bima, Khususnya masyarakat Kecamatan Sape, agar dapat mempertahankan dan melestarikan tradisi yang terkandung dalam Nggahi Ncemba dan dapat menerapkannya dalam kehidupan sehari-hari sebagai makluk Tuhan dan makhluk sosial. Selain itu, dapat menyelamatkan aset budaya tradisional yang merupakan kekayaan bagi masyarakat penggunanya.

2. Pemerintah daerah, khususnya Pemerintah Kabupaten Bima, agar melestarikan kebudayaan Bima melalui kegiatan budaya dan memasukkan Nggahi Ncemba dalam pengajaran Mulok di sekolah-sekolah sebagai bagian pendidikan moral, sosial-ekonomi, dan keagamaan.

\section{DAFTAR PUSTAKA}

Aminuddin. 2004. Pengantar Apresiasi Karya Sastra. Bandung: Sinar Baru Elgensindo.

.1990. Sekitar Masalah Sastra (Beberapa prinsip dan metode pengembangannya). Malang: Yayasan Asih Asah Asuh Malang.

Danandjaja, James. 1984. Folklor Indonesia. Jakarta: Sinar Harapan.

Gaffar, Zainal Abidin. 1991. Struktur Sastra Lisan Serawai. Jakarta: Pusat Pembinaan Dan Pengembangan Bahasa.

Hutomo, Suripan Hadi. 2003. Mutiara Yang Terlupakan (Pengantar Studi Sastra Lisan). Jawa Timur: HISKI.

Jamir, L. Tahir. 2004. Kajian Nilai Pendidikan Folklor Lisan Sasak "Sesenggak" di Lombok Selatan (SKRIPSI). Mataram: FKIP UMM.

Nawawi, Hadari. 1991. Metode Penelitian Bidang Sosial, Cetakan Kelima. Yogyakarta: Gadjah Mada University Press. 


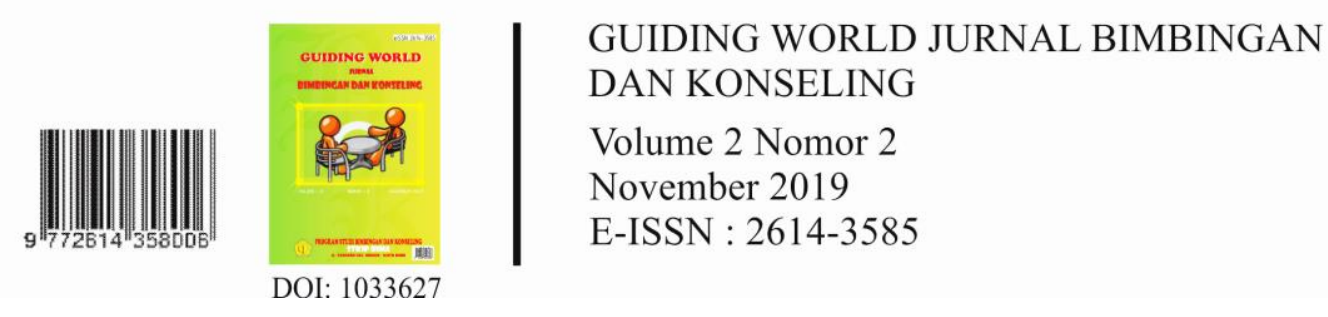

Nazir, Muhammad. 1983. Metode Penelitian. Jakarta: Galfa Indonesia.

Netra, I.B. 1974. Statistik Inferensial. Surabaya: Usaha Pustaka.

Pusat Pembinaan dan Pengembangan Bahasa. 1991. Kamus Besar Bahasa Indonesia (KBBI). Jakarta: Balai Pustaka.

Poewadarminta. 1986. Kamus Besar bahas Indonesia. Jakarta : Balai Pustaka.

Tajib, Abdullah. 1995. Sejarah Bima Dana Mbojo. Raba-Bima: PT. Harapan Masa PGRI.

Zainuddin, Hakim. 1995. Ungkapan Tradisional Makassar. Jakarta: Departemen Pendidikan dan Kebudayaan 